\title{
Being and becoming a teacher: Professional Wellbeing Amidst COVID-19 Pandemic
}

\author{
Dr. Kim Edward S. Santos, Crisanto D. de Jesus. RPm, Engr. Rolando P. Corpuz
}

\author{
1,2Instructor, College of Management and Business Technology, Atate Campus, Nueva Ecija University of Science and Technology, Nueva \\ Ecija, Philippines \\ ${ }^{3}$ Assistant Professor IV, Director, Atate Campus, Nueva Ecija University of Science and Technology
}

Received: 11 Mar 2021; Received in revised form: 07 Apr 2021; Accepted: 18 Apr 2021; Available online: 30 Apr 2021

(C)2021 The Author(s). Published by TheShillonga. This is an open access article under the CC BY license

(https://creativecommons.org/licenses/by/4.0/)

\begin{abstract}
Covid-19 has a significant impact on higher education worldwide, not just in the Philippines. This study described the professional quality of life of the college teachers in terms of compassion satisfaction and compassion fatigue. This study ascertained the relationship of socio demographic profile of the college teachers and their professional quality of life. This study used a quantitative-descriptive method of research. Convenience sampling was used in this study. A total of 76 college instructors were surveyed (44 from public schools and 32 from private schools). Based on the results of the study, it is concluded that the college teachers have high compassion satisfaction for getting satisfaction from being able to teach people, being proud of what they can do to teach, and being happy to their chosen profession. These college teachers have exposure work related secondary traumatic stress on a moderate degree level by having a feeling of worn out because of their work as a teacher and feeling overwhelmed because of their teaching load and other work-related activities. However, the secondary traumatic stress of college teachers did not result to having high level of burnout, though college teachers still experience burnout but in low degree level only.
\end{abstract}

Keywords-COVID-19, Pandemic, college instructor.

\section{INTRODUCTION}

Covid-19 has a significant impact on higher education worldwide, not just in the Philippines. The fact is that lockdown and work and study from home have a substantial and detrimental effect on the learning process in school (Burgess \& Sievertsen, 2020). Further, it was verified that teachers' quality of life deteriorated throughout the pandemic, which according to some studies resulted in negative effects on teachers' mental and physical health (Lizana et al., 2021). On the contrary, despite the moderate to high threat posed by COVID-19, teachers appear to have managed with the virus's impact, as evidenced by the mild impact on their QoL about mental health nearly six months after the country's huge lockdown (Rabacal et al., 2020).

The formation of learning disorders throughout the learning process as a result of the lack of school activities has a negative influence on vulnerable groups, such as young pupils, social disadvantages, learning disabilities, or the setting of family labor to supervise children studying at home (Brown et al., 2020). As suggested, the government's participation in education, through policies, enables students and instructors to have access to the internet and acquire literacy skills (Supriyanto et al., 2020).

To accomplish their objectives, healthy companies must utilize their human resources; they must integrate their programs and empower their workers (Santos \& Nocum, 2020). Further, it is recommended that a company should create a self-care program for contract employees who are suffering burnout (Santos \& De Jesus, 2020).

In light of the foregoing, the researchers would like to assess the college instructors' professional quality of life during the COVID-19 scenario. Additionally, the researchers sought to make recommendations based on the obtained data to assist college faculty and their respective institutions in coping with the pandemic scenario.

\section{OBJECTIVES OF THE STUDY}

This study described the professional quality of life of the college teachers in terms of compassion satisfaction and compassion fatigue. This study ascertained the relationship 
of socio demographic profile of the college teachers and their professional quality of life.

\section{METHODOLOGY}

This study used a quantitative-descriptive research technique, which entails the description, recording, analysis, and interpretation of a real-world condition. When obtaining information on the current state of affairs, it is acceptable to employ the descriptive technique (Creswell,
2014). The study adopted the questionnaire on Professional Quality of Life: Compassion Satisfaction and Fatigue (Stamm, 2010). Convenience sampling was used in this study. A total of 76 college instructors were surveyed (44 from public schools and 32 from private schools). Survey research was employed in this study because it incorporates scientific techniques through critical examination and assessment of source materials, data analysis and interpretation, and generalization and prediction (Salaria, 2012).

\section{RESULTS AND DISCUSSIONS}

Table 1. Professional Quality of Life of College Teachers as to Compassion Satisfaction

\begin{tabular}{|c|c|c|}
\hline Statement & $\begin{array}{l}\text { Weighted } \\
\text { Mean }\end{array}$ & $\begin{array}{c}\text { Verbal } \\
\text { Interpretation }\end{array}$ \\
\hline 1. I get satisfaction from being able to teach people. & 4.53 & Very Often \\
\hline 2. I feel invigorated after working with those I teach. & 4.26 & Very Often \\
\hline 3. I like my work as a teacher/professor. & 4.21 & Very Often \\
\hline $\begin{array}{l}\text { 4. I am pleased with how I am able to keep up with teaching techniques and } \\
\text { protocols. }\end{array}$ & 4.00 & Often \\
\hline 5. My work makes me feel satisfied. & 4.21 & Very Often \\
\hline $\begin{array}{l}\text { 6. I have happy thoughts and feelings about those I teach and how I could help } \\
\text { them. }\end{array}$ & 4.26 & Very Often \\
\hline 7. I believe I can make a difference through my work. & 4.16 & Often \\
\hline 8. I am proud of what I can do to teach. & 4.42 & Very Often \\
\hline 9. I have thoughts that I am a "success" as a teacher/professor. & 4.16 & Often \\
\hline 10. I am happy that I chose to do this work. & 4.42 & Very Often \\
\hline Total Weighted Mean & 42.63 & High Level \\
\hline
\end{tabular}

This domain is about the pleasure a teacher can experience from being able to help others and to make a positive difference in the world.

Based on the result, the compassion satisfaction of the college teachers has a sum of the weighted means of 42.63 with a high level degree. Item 1 got the highest mean of 4.56 with verbal description of 'very often' among other items in this domain. This item suggests that very often these college teachers get satisfaction from being able to teach people. Further, it can be supported by the Items 8 and 10 which got a mean rating of 4.42 with a verbal description of 'very often'. These describe how the college teachers are proud of what they can do to teach and how happy they are in choosing teaching as their work.

Table 2. Professional Quality of Life of College Teachers as to Burnout

\begin{tabular}{llcr}
\hline \multicolumn{1}{c}{ Statement } & Weighted & Mean & $\begin{array}{c}\text { Verbal } \\
\text { Interpretation }\end{array}$ \\
\hline 1. I am happy. & 1.63 & Very often \\
2. Ifeel connected to others. & 1.53 & Very often \\
3. I am not as productive at work because I am losing sleep over traumatic & 1.79 & Never \\
& experiences of a person I teach. & 2.05 & Rarely
\end{tabular}


5. I have beliefs that sustain me.

1.79

2.00

2.79

3.21

2.58

1.63

21
Very Often

Often

Sometimes

Sometimes

Rarely

Very often

Low Level

Note: Italicized statements were reverse scored

Based on the responses of the school college teachers, the sum of the weighted means of this domain is 21 with low level degree. This implies college teachers are associated with low feelings of hopelessness and difficulties in dealing with work or in doing their job effectively.

However, it can be noticed on item 8 (mean $=3.21$; verbal interpretation $=$ sometimes $)$ that it has the highest mean among the other items. This describes of feeling overwhelmed because of their teaching load seems endless.
This can be attributed to other schoolwork of the college teachers aside from teaching.

Other reasons that college teachers have low level degree of burnout are can be found on their responses on Items 1, 2, 5 and 10 and all has verbal description 'very often'. This illustrates that college teachers are happy $($ mean $=1.63)$, feel connected to others $($ mean $=1.53)$, have beliefs that sustain them (mean $=1.79)$, and very caring persons $($ mean $=1.63)$.

Table 3. Professional Quality of Life of College Teachers as to Secondary Traumatic Stress

\begin{tabular}{|c|c|c|}
\hline Statement & Weighted & \\
\hline 1. I am preoccupied with more than one person I teach. & 3.79 & Often \\
\hline 2. I jump or am startled by unexpected sounds. & 3.42 & Often \\
\hline $\begin{array}{l}\text { 3. I find it difficult to separate my personal life from my life as a } \\
\text { teacher/professor. }\end{array}$ & 2.53 & Rarely \\
\hline 4. I think that I might have been affected by the traumatic stress of those I teach. & 2.00 & Rarely \\
\hline 5. Because of my teaching, I have felt "on edge" about various things. & 2.63 & Sometimes \\
\hline 6. I feel depressed because of the traumatic experiences of the people I teach. & 1.84 & Rarely \\
\hline 7. I feel as though I am experiencing the trauma of someone I have taught. & 2.21 & Rarely \\
\hline $\begin{array}{l}\text { 8. I avoid certain activities or situations because they remind me of frightening } \\
\text { experiences of the people I teach. }\end{array}$ & 2.79 & Sometimes \\
\hline 9. As a result of my teaching, I have intrusive, frightening thoughts. & 2.53 & Rarely \\
\hline 10. I can't recall important parts of my work with trauma victims. & 2.37 & Rarely \\
\hline Total Weighted Mean & 26.11 & Moderate Level \\
\hline
\end{tabular}

Secondary traumatic stress may lead to compassion fatigue, where exposure to work related secondary stressful events are present. It was found out that the college teachers have a moderate degree level of secondary traumatic stress with a sum of weighted means of 26.11 .
This was also shown in this domain that Item 1 got the highest mean of 3.79 with a verbal description of 'often'. This item describes that college teachers are often preoccupied with more than one person they teach. Further, they the jump or startled by unexpected sounds (mean = 3.42 , verbal interpretation $=$ often). This experience is usually observed to people under traumatic stress. 
Table 4. Summary of the Professional Quality of Life of College Teachers

\begin{tabular}{lcc}
\hline Domain & Total Weighted Mean & Verbal Interpretation \\
\hline Compassion Satisfaction & 42.63 & High Level \\
Burnout & 21 & Low Level \\
Secondary Traumatic Stress & 26.11 & Moderate Level \\
\hline
\end{tabular}

Based on table 4, the summary of the professional quality of life of college teachers is composed of the combination of high degree of level in compassion satisfaction (mean $=42.63$ ), low degree of level in burnout $($ mean $=21)$ and average degree of level in secondary traumatic stress $($ mean $=26.11)$. This implies a positive result. It means that despite of some secondary traumatic

Table 5. Correlation of the College Teachers' Demographic Profile and their Professional Quality of Life

\begin{tabular}{|c|c|c|c|c|c|c|c|}
\hline & Age & Sex & $\begin{array}{l}\text { Highest } \\
\text { Educational } \\
\text { Attainment }\end{array}$ & $\begin{array}{c}\text { Number of Years } \\
\text { in teaching } \\
\text { profession }\end{array}$ & $\begin{array}{l}\text { Compassion } \\
\text { Satisfaction }\end{array}$ & Burnout & $\begin{array}{c}\text { Secondary } \\
\text { Traumatic } \\
\text { Stress }\end{array}$ \\
\hline Age & 1 & & & & & & \\
\hline Sex & .002 & 1 & & & & & \\
\hline Highest & .455 & .000 & 1 & & & & \\
\hline $\begin{array}{l}\text { Educational } \\
\text { Attainment }\end{array}$ & & & & & & & \\
\hline $\begin{array}{l}\text { Number of Years in } \\
\text { teaching profession }\end{array}$ & $.807 * *$ & .197 & .412 & 1 & & & \\
\hline $\begin{array}{l}\text { Compassion } \\
\text { Satisfaction }\end{array}$ & -.166 & -.127 & -.155 & -.077 & 1 & & \\
\hline Burnout & -.135 & -.125 & .417 & -.033 & -.326 & 1 & \\
\hline $\begin{array}{l}\text { Secondary } \\
\text { Traumatic }\end{array}$ & -.142 & -.311 & $.475^{*}$ & -.145 & .232 & $.650 * *$ & 1 \\
\hline Stress & & & & & & & \\
\hline
\end{tabular}

stresses the college teachers had experienced this only resulted to low burnout. In fact, these college teachers find satisfaction from their work and being able to teach others that They experience happy thoughts, feel successful, are happy with the work they do, want to continue to do it, and believe they can make a difference.

\footnotetext{
** Correlation is significant at the 0.01 level (2-tailed).
}

* Correlation is significant at the 0.05 level (2-tailed).

Results show that highest educational attainment is positively related to secondary traumatic stress $(r=.475, p$ $<.05)$. This indicates that college teachers with high educational attainment have high secondary traumatic stress. But based on the computed $r$ value, it only means it has a moderate correlation. Furthermore, secondary traumatic stress is positively related to burnout ( $r=.650, p$ $<.01)$; strong correlation. This implies that if the college teachers have high exposure to secondary traumatic stress they will more likely to have high level of burnout.

\section{CONCLUSIONS AND RECOMMENDATIONS}

Based on the results of the study, it is concluded that the college teachers have high compassion satisfaction for getting satisfaction from being able to teach people, being proud of what they can do to teach, and being happy to their chosen profession. These college teachers have exposure work related secondary traumatic stress on a moderate degree level by having a feeling of worn out because of their work as a teacher and feeling overwhelmed because of their teaching load and other work related activities. However, the secondary traumatic stress of college teachers did not result to having high level of 
burnout, though college teachers still experience burnout but in low degree level only.

The following recommendations were drawn from the findings and conclusions:

1. Individual scores of the college teachers' professional quality of life should be explored to identify whose teachers, most possibly, have moderate to high level of secondary traumatic stress and burnout for them to get an intervention from the institution;

2. Determine the coping strategies used by the college teachers in order for them to handle stress and burnout;

3. Identify the specific problems or challenges the college teachers are experiencing; and

4. Determine what secondary traumatic stress the college teachers get from teaching people.

\section{REFERENCES}

[1] Brown, N., Te Riele, K., Shelley, B., \& Woodroffe, J. (2020). Learning at home during COVID-19: Effects on vulnerable young Australians. Peter Underwood Centre for Educational Attainment.

[2] Burgess, S., \& Sievertsen, H. H. (2020). Schools, skills, and learning: The impact of COVID-19 on education. VoxEu. org, l(2).

[3] Creswell, J. W. (2014). A concise introduction to mixed methods research. SAGE publications.

[4] Lizana, P. A., Vega-Fernadez, G., Gomez-Bruton, A., Leyton, B., \& Lera, L. (2021). Impact of the COVID-19 Pandemic on Teacher Quality of Life: A Longitudinal Study from before and during the Health Crisis. International Journal of Environmental Research and Public Health, 18(7), 3764.

[5] Rabacal, J., Oducado, R. M., \& Tamdang, K. (2020). COVID-19 impact on the quality of life of teachers: A crosssectional study. Asian Journal for Public Opinion Research, 8(4), 478-492.

[6] Salaria, N. (2012). Meaning of the term descriptive survey research method. International journal of transformations in business management, 1(6), 1-7.

[7] Santos, K. E. S., \& De Jesus, C. D. (2020). Job Burnout of Contractual Workers in Nueva Ecija. Open Access Library Journal, 7(2), 1-9.

[8] Santos, K. E. S., \& Nocum, C. L. R. (2020). Organizational Condition of Private Schools and Colleges in Nueva Ecija. Open Access Library Journal, 7(2), 1-8.

[9] Stamm, B. H. (2010). The ProQOL test manual. Retrieved from http://www.proqol.org/ProQO1_Test_Manuals.html

[10] Stamm, B. H. (2010). Professional quality of life: Compassion satisfaction and fatigue (Version 5). Retrieved from http://www.proqol.org/uploads

[11] Supriyanto, A., Hartini, S., Irdasari, W. N., Miftahul, A., Oktapiana, S., \& Mumpuni, S. D. (2020). Teacher professional quality: Counselling services with technology in Pandemic Covid-19. Counsellia: Jurnal Bimbingan dan Konseling, 10(2), 176-189. 